1. American Thoracic Society Commitiec on Diagnostic Standards for nontuberculous Diseases: Definitions and classification of chronic bronchitis, asthma and pulmonary emphysema. Am. Rev. Respir. Dis., 85: 762 (1962).

2. Cogswell. J. J.: Forced oscillation technique for determination of resistance to breathing in children. Arch. Dis. Child.. 48: 259 (1973).

3. DuBois. A. B., Botelho. S. Y.. and Comroe. J. H.: A new method for measuring airway resistance in man using a body plethysmograph: Values in normal subjects and in patients with respiratory disease. J. Clin. Invest., 35: 327 (1956).

4. DuBois. A. B., Brody, A. W.. Lewis. D. H., and Burgess, B. F.. Jr.: Oscillation mechanics of lungs and chest in man. J. Appl. Physiol. 8: 587 (1956).

5. Fisher. A. B. DuBois, A. B., and Hyde. R. W.: Evaluation of the foreed oscillation technique for the determination of resistance to breathing. J. Clin. Invest $47 \cdot 2045(1968)$

6. Goldman. M.. Knudson. R. J.. Mead. J. Peterson. V., Schwaber. J. R.. and Wohl. M. E.: A simplified measurement of respiratory resistance by forced oscillation. J. Appl. Physiol.. 28: 113(1970)

7. Grimby. G. Takishima. T., Graham. W. Macklem. P.. and Mead. J.: Frequency dependence of flow resistance in patients with obstructive lung disease J Clin. Invest. 47:1455(1968).

8. Holle, J. P.. Landser. F.. Schüller. B., Hartmann, V.. and Magnussen. H.:
Measurement of respiratory mechanics with forced oscillations. Respiration. $41 \cdot 119(1981)$

9. Landau, L. I. and Phelan, P. D.: Evaluation of two techniques for measurement of respiratory resistance by forced oscillation. A study in young subjects with obstructive lung discase. Thorax, 28: 136 (1973).

10. Ländśer. F. J.. Nagels, J., and van de Woestijne. K. P.: Implementation by means of microprocessor techniques for the measurement of total respiratory impedance during spontaneous breathing. Prog. Respir. Res.. 11: 135 (1979).

11. Lenney. W. and Milner. A. D.: At what age do bronchodilator drugs work? Arch. Dis. Child., 53: 532 (1978).

12. Mansell. A. Levinson. H. Kruger. K and Tripp $\Upsilon$. L. Measurement of respiratory resistance in children by forced oscillations. Am. Rev. Respir. Dis. 106:710 (1972)

13. Wanner, A.. Zarzecki. S., and Marks. M. D.: Continuous measurement of respiratory resistance in asthmatic children. Respiration, 34: 61 (1977).

14. The authors wish to thank Cheryl Nichols for her assistance in the preparation of this manuscript.

15. Requests for reprints should be addressed to: Dr. Eliczer Nussbaum. Director Pediatric Pulmonary Center and Intensive Care Unit. Miller Children`s Hospital Medical Center. 2801 Atlantic Avenue. Long Beach. CA 90801.

16. Supported in part by a Grant from the Medical Department of the Bochringer Ingelheim Company.

17. Received for publication June 3,1982

18. Accepted for publication February 18.1983

\title{
Intestinal Development in the Suckling Rat: Effects of Weaning, Diet Composition, and Glucocorticoids on Thymidine Kinase Activity and DNA Synthesis
}

\author{
JEAN-PAUL BUTS ${ }^{(42)}$ AND ROGER DE MEYER \\ Division of Experimental Teratologl and Medical Genetics, Department of Pediatrics. Lniversits of Louvain \\ Brussels, Belgium
}

\begin{abstract}
Summary
The present study was designed to determine whether the ontogenic changes in the salvage pathway for DNA synthesis of suckling rat intestine could be causally related to physiologic events during the weaning period. The intestinal activity of soluble thymidine kinase, extremely low in young sucklings (d 11, $0.057 \pm 0.007 \mathrm{nmol} \cdot \mathrm{min}^{-1} \cdot \mathrm{g}$ tissue ${ }^{-1}$ ), increased dramatically between $d 18$ and 22 postpartum and reached a plateau (19.8 \pm $0.5 \mathrm{nmol} \cdot \mathrm{min}^{-1} \cdot \mathrm{g}$ tissue ${ }^{-1}$ ) at the fourth postnatal week. Rat pups prevented from weaning showed an initial rise in the enzyme synthesis by $\mathrm{d} 18$ as did their littermates weaned onto an adult diet. Compared with 22-d-old rats weaned onto chow pellets (14.1 $\pm 2.1 \mathrm{nmol} \cdot \mathrm{min}^{-1} \mathrm{~g}$ tissue $\mathrm{e}^{-1}$ ), thymidine kinase concentration was reduced by one-half in rats of the same age, fed on mother's milk alone $\left(6.5 \pm 0.7 \mathrm{nmol} \cdot \mathrm{min}^{-1} \cdot \mathrm{g}\right.$ tissue $\left.{ }^{-1}\right)$ or on a liquid artificial diet either high in fat (mimicking rat milk, $7.4 \pm 0.6$ $\mathrm{nmol} \cdot \mathrm{min}^{-1} \cdot \mathrm{g}$ tissue ${ }^{-1}$ ) or high in carbohydrate mimicking chow, $6.4 \pm 1.3 \mathrm{nmol} \cdot \mathrm{min}^{-1} \cdot \mathrm{g}$ tissue $\mathrm{e}^{-1}$ ). The relative proportions of fat and carbohydrate in the diet had little or not effect on growth rate, intestinal wt, and DNA content per centimeter. In a second experiment, 9-d-old sucklings were treated for four consecutive d with either saline or hydrocortisone hemisuccinate at doses assumed to be in the physiologic $(0.5 \mathrm{mg} / 100 \mathrm{~g}$ body wt per day $)$
\end{abstract}

and pharmacologic $(2.0 \mathrm{mg} / 100 \mathrm{~g}$ body wt per day) range. Low doses of the steroid failed to enhance precociously the intestinal synthesis of the enzyme and produced significant decreases in intestinal protein $(-19 \%$ versus controls, $P<0.05)$ and DNA content $(-23 \%, P<0.01)$. In the jejunum as well in the ileum, the incorporation rates of $\left[{ }^{3} \mathrm{H}\right]$ thymidine into DNA were reduced to a level about $70 \%$ of the controls $(P=0.05)$. Higher doses of hydrocortisone had a marked suppressive effect on DNA synthesis in the jejunum and ileum, the values in the steroid-treated group being about one-half those of the control group.

During the third week of postnatal life, profound morphologic and biochemical changes occur in rat small intestine. These include increases in intestinal weight, villus and crypt height, cell migration rate, and RNA and DNA content $(16,24)$. The enhanced cell proliferation leads to mucosal hyperplasia, which equally develops in the entire small bowel (3). Intestinal enzymatic activity also undergoes rapid adaptation between $\mathrm{d} 14$ and 21 (14). All these intestinal changes are in the direction of adult values and in many cases, overshoot adult levels. The physiologic mechanisms that initiate and control these maturative events are not well understood. Rats initiate weaning (dietary transition from rat milk to chow) at a critical period, when the intestinal 
development is at its peak. Lichtenberger and Johnson (27) have shown that the prevention of weaning in rats retarded normal intestinal development. Intestinal wet weight, and RNA and protein content relative to body weight were significantly lower in nonweaned pups than in weaned littermates. Although there is a temporal correlation between intestinal maturation and the spontaneous process of weaning, the possibility that the ontogenic changes in cell proliferation are diet-initiated has been discredited. For example, the prevention of weaning failed to alter the onset of maturative changes in mitotic index and crypt/ villus height ratio (26). The converse type of experiment (i.e., determining whether early weaning causes precocious maturation of an enzyme or function), although repeatedly performed $(16,35)$, is difficult to interpret because early gavage feeding undoubtedly stresses the animals and elevates plasma corticosterone (6), which may be a true activator. Indeed, there is considerable evidence that hormonal mediators including corticosterone, gastrin and thyroxine are intimately involved in the regulation of intestinal maturation (14). Administration of glucocorticoids to the suckling rat will induce the precocious appearance or increase of alpha-glucosidases $(1,5,9,11)$, ileal bile salt transport (28), pinocytosis (23) and the uptake of immunoglobulins (34). Conversely, adrenalectomy of the suckling rat will prevent the occurrence of maturational events at the appropriate time. Although adrenal cortical hormones play a determinant role in the maturation of differentiated villous cell functions, it is uncertain whether they could initiate changes in cell proliferation and DNA synthesis. Up to the present time, the effects of exogenous administration of glucocorticoids on intestinal morphology, on cell proliferation rates and on DNA synthesis in suckling rat intestine have been examined very little and previous experiments with cortisone $(24,29)$ and hydrocortisone (16) have led to conflicting results.

In order to clarify further the role of weaning and of glucocorticoid secretion in intestinal development, we have studied the effects of changes in weaning time and diet composition on parameters of DNA synthesis in suckling rat intestine. We also assessed the effects of low and high doses of hydrocortisone on intestinal synthesis of DNA and of thymidine kinase.

\section{MATERIALS AND METHODS}

Animals. Wistar rats housed in opaque polystyrene cages in an air conditioned room at $22 \pm 11^{\circ} \mathrm{C}$ with 12 -h light-dark cycle were used throughout this study. The day of birth was defined as $\mathrm{d} 0$. Sucklings remained from $\mathrm{d} 0$ with their mother and had free access to the nipples. The rats were weaned at $d 21$ postpartum and were fed at libitum a solid stock died $\left(\mathrm{AO}_{3}, \mathrm{UAR}\right.$, Villemoisson-sur-Orge, France). They were allowed to drink unrestricted amounts of water.

Ontogenic changes (experiment I). The postnatal changes in intestinal thymidine kinase synthesis were studied in eight groups of four rats each killed at the following ages: 4, 11, 16, 18, 22, 26,34 , and $50 \mathrm{~d}$ postpartum. The incorporation of $\left[{ }^{3} \mathrm{H}\right]$ thymidine into jejunal and ileal DNA in vivo was also measured in 14 d-old and 25-d-old rats.

Weaning (experiment II). Young rats of one litter were prevented from weaning and were kept with a lactating mother in plastic cages. The pups were allowed to drink water or suckle freely but were given no access to solid food. The lactating mother was changed every $12 \mathrm{~h}$ and this rotation process was continued throughout the period of the experiment. Three groups of four rats each were sacrificed respectively at d 18, 22, and 26 .

Diet composition (experiment III). Two litters of six rats each were weaned by day 16 onto a high fat-liquid diet (rat-like, containing $29 \%$ lactose and $50 \%$ fat per 100 gram of solid) or onto a high carbohydrate diet (chow-like, containing 59\% lactose and $21 \%$ fat per 100 gram of solid). The feeding techniques and the composition of the diets have been published in detail by Henning and Guerin (15). The pups had no access to solid food and were housed in metabolic cages to avoid coprohagia during the experimental period. The diets were administered in calibrated bottles. Fresh diet was provided twice daily and the amount of liquid consumed was noted. The rats of both groups were sacrificed at $\mathrm{d} 22$.

Hormonal treatment (experiment $I V$ ). Hydrocortisone hemisuccinate (Solucortef, Upjohn) was injected subcutaneously into 9-d-old sucklings on consecutive days for four d before sacrifice (day 12). The doses used were 0.5 and $2.0 \mathrm{mg} / 100 \mathrm{~g}$ body wt per day. Littermates from each group served as controls and were treated with an equivalent volume of saline according to the same schedule. All injections were made at 3.00 PM with the last injection $2 \mathrm{~h}$ before death.

Tissue preparation and assays. On the day of the experiment, the animals were killed by cervical transection. The abdominal cavity was immediately opened and the entire length of the small intestine was excised from the pylorus to the caecum. The intestine was rinsed in cold saline $(0.9 \%)$, measured under fixed tension, and divided into two equal segments. The proximal half was defined as the jejunum and the distal half as the ileum. Both pieces were opened lengthwise, rinsed thoroughly with ice cold saline $(0.9 \%)$ and weighed on a Mettler balance. The segments were wrapped in parafilm and frozen immediately.

All determinations were made within $1 \mathrm{wk}$ of collection. Thymidine kinase activity (EC 2.7.1.75) was measured in the cytosol fraction of whole intestinal homogenates. Freshly prepared tissue was used because the enzyme was found to be unstable in cytosol when stored overnight at +4 or $-20^{\circ} \mathrm{C}$. The assays were based on the procedure described by Machovich and Greengard (31) with modifications according to Herzfeld et al. (20). The final concentration of thymidine was $0.04 \mathrm{mM}\left(\left[{ }^{14} \mathrm{C}\right]\right.$ 2-thymidine, specific activity $54-56 \mathrm{mCi} / \mathrm{mmol}, 50 \mu \mathrm{Ci} / \mathrm{ml}$, Amersham, Buckinghamshire, England). After incubating the reaction mixtures in total volumes of $0.5 \mathrm{ml}$ for $20 \mathrm{~min}$ at $37^{\circ} \mathrm{C}$, $50 \mu \mathrm{l}$ was pipetted onto Whatman aminoethyl cellulose discs (DE 81, Whatman, England). Non-phosphorylated thymidine was eluted by stirring the discs in $500 \mathrm{ml}$ of cold $1.0 \mathrm{mM}$ ammonium formate for $15 \mathrm{~min}$ followed by successive alternating 5-min washes of water and $95 \%$ ethanol. The discs were counted in $9.0 \mathrm{ml}$ Aqualuma (Lumac, Schaesberg, Holland) in a Beckman scintillation counter, with an absolute activity analyzer for quench correction and $90 \%$ efficiency. Enzyme activities were expressed as $\mathrm{nmol} \cdot \mathrm{min}^{-1} \cdot \mathrm{g}$ tissue ${ }^{-1}$. For the determination of DNA synthesis rates, $2 \mu \mathrm{Ci} / \mathrm{g}$ body wt of $\left[{ }^{3} \mathrm{H}\right]$ thymidine (specific activity, $23 \mathrm{Ci} / \mathrm{nmol}$, Amersham, England) was injected intraperitoneally into each animal. The injections were all given at the same hour in the morning to circumvent circadian periodicity in DNA synthesis (11). The animals were sacrificed after $120 \mathrm{~min}$. Tissue samples $(100 \mathrm{mg})$ of the jejunum and ileum were homogenized in $8 \mathrm{ml}$ of $0.25 \mathrm{~N}$ cold perchloric acid. DNA was extracted by serial precipitation in perchloric acid as described by Johnson and Guthrie (22) and assayed by the diphenylamine method of Burton (2) modified by Giles and Myers (10). Polymerized calf thymus DNA (Sigma, Chemicals) was used as standard. The amount of $\left[{ }^{3} \mathrm{H}\right]$ thymidine incorporated into DNA was determined by counting $1 \mathrm{ml}$ of the extract in a liquid scintillation system. DNA extracts were counted in triplicate. Protein content was measured by the Lowry method (30).

Calculations. Unless otherwise stated, all results concern the whole intestine and were expressed as mean \pm SE. DNA was calculated in $\mathrm{mg} / \mathrm{g}$ of tissue, $\mathrm{mg} / \mathrm{cm}$ of intestinal length and DNA synthesis rates in (dis/min) $/ \mathrm{mg}$ of DNA and $(\mathrm{dis} / \mathrm{min}) / \mathrm{cm}$ of intestine. Differences between means were tested for statistical significance $(P<0.05)$ using the unpaired Student's $t$ test.

\section{RESULTS}

The developmental changes of thymidine kinase (soluble fraction) in rat small intestine are depicted in Figure 1. In sucklings, the enzymatic activity remained fairly constant between $\mathrm{d} 4$ and 16 , averaging $0.057 \mathrm{nmol} \cdot \mathrm{min}^{-1} \cdot \mathrm{g}$ tissue ${ }^{-1}$. At $18 \mathrm{~d}$ of age, thymidine kinase synthesis markedly increased, reaching a peak 




Fig. 1. Ontogenic changes in thymidine kinase activity (soluble fraction) of rat small intestine. Each closed circle represents the mean $\pm \mathrm{SE}$ of eight observations obtained from four rats. Arrow's delineate the weaning period (d 14-22). In weaning rats, the enzyme activity increased markedly and reached a plateau at the fourth postnatal week. Unweaned rats, fed on mother's milk alone, exhibited a rise in enzyme synthesis by d 18 as did their littermates weaned onto chow. The activity plateau was reduced by two-thirds in rats prevented from weaning.

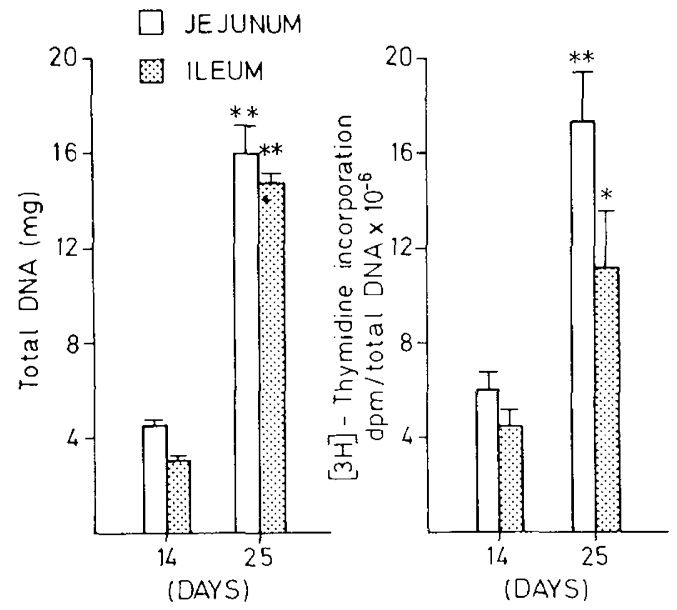

Fig. 2. Total DNA content and total incorportion of $\left[{ }^{3} \mathrm{H}\right]$ thymidine into DNA per jejunum and ileum. measured in sucklings (14-d-old) and weaned (25-d-old) rats. Results represent means \pm SE of $7-10$ observations. ${ }^{* *} P<0.0005$ as compared with 14 -d-old rats. $* P<0.01$ as compared with 14-d-old rats.

at $\mathrm{d} 28\left(19 \mathrm{nmol} \cdot \mathrm{min}^{-1} \cdot \mathrm{g}\right.$ tissue $\left.\mathrm{e}^{-1}\right)$. Figure 2 shows that the rise in thymidine kinase activity at weaning is concomitant with a 3 -4-fold increase in total DNA content and in total $\left[{ }^{3} \mathrm{H}\right]$ thymidine incorporation into DNA per jejunum or ileum. The results of experiments II and III demonstrate that the postnatal rise in thymidine kinase activity, initiated at the end of the third postnatal week, was not causally related to the dietary changes of the weaning period. Suckling pups used in the study already supplemented their milk with solid food from d 15, whereas the peak of enzyme accumulation was delayed until the fourth postnatal week. This is further attested by the fact that rats which were prevented from weaning exhibited an initial rise in the enzyme synthesis between $\mathrm{d} 18$ and 22 , similar to that of their littermates weaned onto a solid adult diet (Fig. 1). By d 22 and 26 , thymidine kinase activity was significantly lower in unweaned than in weaned rats (57 and $37 \%$ of the mean values obtained in the weaned group, $P<0.05$ ). With regard to the nature of dietary changes at weaning, rat milk is low in carbohydrate and high in fat and the converse is true for the normal weaning dict
(7). To test whether this difference in relative proportions could affect intestinal DNA content and thymidine kinase concentrations, suckling pups were weaned at d 16 onto either a liquid diet that mimicked rat milk in composition (low carbohydrate, high fat) or onto a diet that mimicked chow (high carbohydrate, low fat). The results are presented in Figures 3 and 4 . The pups grew just as well on the high carbohydrate diet as on the low carbohydrate diet (Fig. 3), and dietary consumption measured daily was equivalent $(15-20 \mathrm{ml} / \mathrm{rat})$ in both groups. At the age of $22 \mathrm{~d}$, there was no difference in intestinal weight/cm (Fig. 3), thymidine kinase activity (Fig. 4) and intestinal DNA content/ $\mathrm{cm}$ (Fig. 4) between the two groups. From the results shown in Figures $l$ and 4 , it appears that the enzyme activity was equivalent in 22-d-old rats fed on mother's milk $(6.5 \pm 0.7 \mathrm{nmol}$. $\min ^{-1} \cdot \mathrm{g}$ tissue $\left.{ }^{-1}\right)$ and in those fed on liquid diets either high in fat $\left(7.4 \pm 0.6 \mathrm{nmol} \cdot \mathrm{min}^{-1} \cdot \mathrm{g}\right.$ tissue $\left.\mathrm{e}^{-1}\right)$ or high in carbohydrate $\left(6.4 \pm 1.3 \mathrm{nmol} \cdot \mathrm{min}^{-1} \cdot \mathrm{g}\right.$ tissue $\left.{ }^{-1}\right)$.

The postnatal rise in thymidine kinase activity and the parallel increase in intestinal DNA is preceded by an upsurge in total plasma corticosterone between d 14 and $18(4,13)$. To determine whether the changes in intestinal DNA synthesis could be initiated or influenced by glucocorticoid secretion, we injected low doses $(0.5 \mathrm{mg} / 100 \mathrm{~g}$ body wt) of hydrocortisone into 9-d-old sucklings for 4 consecutive $d$. The results of the intestinal parameters obtained in hydrocortisone-treated-rats are compared with those of saline-treated-littermates in Table 1. Low doses of hydrocortisone did not alter growth rate, gut length, or enteric weight per centimeter but depressed significantly intestinal protein $(-19 \%, P<0.05)$ and DNA content, expressed per milligram of tissue $(-23 \%, P<0.01)$ or per centimeter of length $(-21 \%, P$ $<0.05)$. The activity of thymidine kinase was also $42 \%$ lower in

\section{LIQUID DIETS}



Fig. 3. Growth rate of pups weaned by 16 onto a liquid milk-based diet either high in fat or high in carbohydrate. The rats grew just as well on the high carbohydrate diet as on the high fat one. Enteric weight $/ \mathrm{cm}$ was equivalent in 22-d-old rats fed on the high fat $(F)$ or on the high carbohydrate $(\mathrm{C})$ diet.

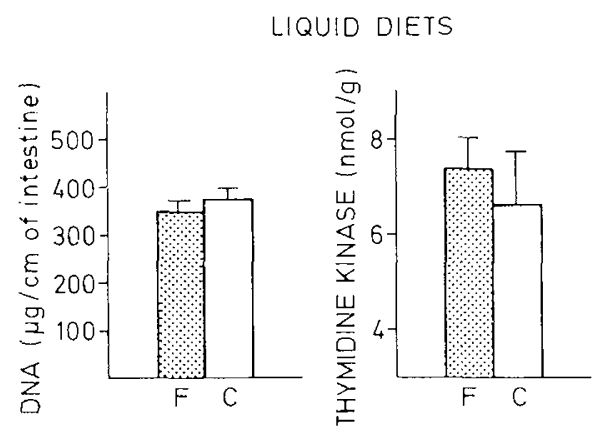

Fig. 4. Intestinal DNA content and thymidine kinase activity in 22d-old rats. weaned by d 16 onto a liquid diet either high in fat $(F)$ or high in carbohydrate (C). The differences in DNA content and thymidine kinase activity between the two groups were small and not statistically significant. 
Table 1. Intestinal wt, protein, DNA, and thymidine kinase activity in suckling rats treated with hydrocortisone hemisuccinate $(0.5 \mathrm{mg} / 100 \mathrm{~g}$ body weight) or saline from $d 9$ until d 12 postpartum

\begin{tabular}{|c|c|c|c|c|}
\hline & Controls & $\begin{array}{l}\text { Hydro- } \\
\text { cortisone }\end{array}$ & $\begin{array}{c}\% \text { of } \\
\text { controls }\end{array}$ & $P$ \\
\hline$n$ & $(6)^{*}$ & (6) & & \\
\hline \multicolumn{5}{|l|}{ Body wt (g) } \\
\hline Initial & $21.3 \pm 0.9 \dagger$ & $21.4 \pm 0.6$ & & \\
\hline Final & $27.3 \pm 1.1$ & $28.3 \pm 0.7$ & 103 & NSt \\
\hline $\begin{array}{c}\text { Intestinal wt } \\
(\mathrm{mg} / \mathrm{cm})\end{array}$ & $19 \pm 0.3$ & $20 \pm 1$ & 105 & NS \\
\hline $\begin{array}{l}\text { Intestinal length } \\
(\mathrm{cm})\end{array}$ & $43.2 \pm 1.1$ & $48.1 \pm 1.1$ & 111 & NS \\
\hline $\begin{array}{l}\text { Protein } \\
\quad(\mathrm{mg} / \mathrm{cm})\end{array}$ & $160 \pm 5.3$ & $136 \pm 6.7$ & 81 & $<0.05$ \\
\hline DNA & & & & \\
\hline $\begin{array}{l}\text { (mg/g tissue) } \\
(\mathrm{mg} / \mathrm{cm})\end{array}$ & $\begin{array}{c}10.6 \pm 0.2 \\
0.211 \pm 0.007\end{array}$ & $\begin{array}{c}8.6 \pm 0.5 \\
0.173 \pm 0.017\end{array}$ & $\begin{array}{l}77 \\
79\end{array}$ & $\begin{array}{l}<0.01 \\
<0.05\end{array}$ \\
\hline Protein/DNA & $15.1 \pm 0.7$ & $16.4 \pm 1.3$ & 108 & NS \\
\hline Thymidine kinases & $0.040 \pm 0.007$ & $0.028 \pm 0.004$ & 58 & NS \\
\hline
\end{tabular}

* Numbers in parentheses are number of rats studied.

$\dagger$ Values are mean $\pm \mathrm{SE}$.

$+P$. probability versus controls

$\S$ units, $\mathrm{nmol} \cdot \mathrm{min}^{-1} \cdot \mathrm{g}$ tissue $\mathrm{e}^{-1}$.

\section{DNA SYNTHESIS}
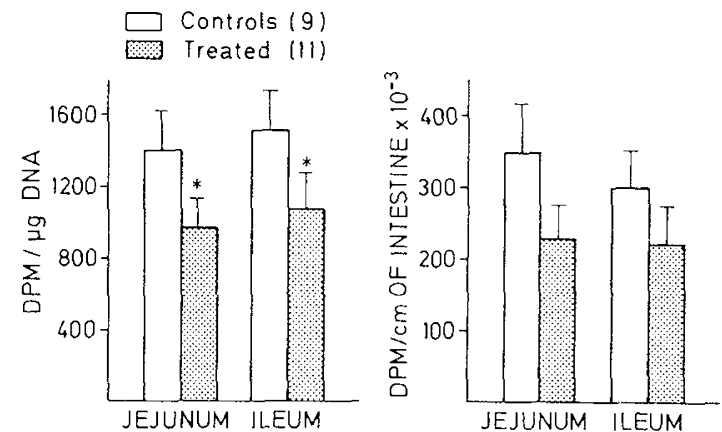

Fig. 5. Effects of low doses of hydrocortisone $(0.5 \mathrm{mg} / 100 \mathrm{~g}$ body wt $)$ on DNA synthesis rates in the jejunum and ileum of suckling rats (see text for treatment schedule). Numbers in parentheses are the numbers of rats studied. In the steroid-treated group, the incorporation rates of $\left[{ }^{3} \mathrm{H}\right]$ thymidine (cxpressed per mg of DNA) were decreased to $69 \%$ (jejunum, $* P=0.05$ ) and $71 \%$ (ileum, $* P=0.05$ ) of the controls. Expressed per centimeter of intestine, the incorporation rates were decreased in the same proportions but the changes were not significant.

the hydrocortisone-treated group than in the control group but the difference did not prove to be statistically significant. Subsequently, we assessed the effects of low $(0.5 \mathrm{mg} / 100 \mathrm{~g}$ body wt) and high $(2.0 \mathrm{mg} / 100 \mathrm{~g}$ body $\mathrm{wt})$ doses of hydrocortisone on DNA synthesis rates in the jejunum and ileum of suckling rats. The treatment schedule was identical to that described above. In rats treated with low doses of the steroid (Fig. 5) the incorporation rate of $\left[{ }^{3} \mathrm{H}\right]$ thymidine expressed in (dis/min)/mg of DNA was decreased to a level $69 \%$ of the controls in the jejunum $(P=$ $0.05)$ and to $71 \%$ of the controls in the ileum $(P=0.05)$. When expressed in $(\mathrm{dis} / \mathrm{min}) / \mathrm{cm}$ of intestine, the decreases in incorporation rates were of the same magnitude but the differences were not significant. Pharmacologic doses of hydrocortisone were associated with constant decreases in body wt (data not shown). Jejunal and ileal wet weight per $\mathrm{cm}$ was also significantly lower in treated than in non-treated rats (jejunum $(\bar{x} \pm \mathrm{SE}), 21.9 \pm 0.6$ versus $25.9 \pm 1.1 \mathrm{mg} / \mathrm{cm}, P<0.05$; ileum, $12.9 \pm 0.3$ versus $16.7 \pm 0.7 \mathrm{mg} / \mathrm{cm}, P<0.01)$. As shown in Figure 6 , high doses of hydrocortisone depressed significantly the incorporation rate

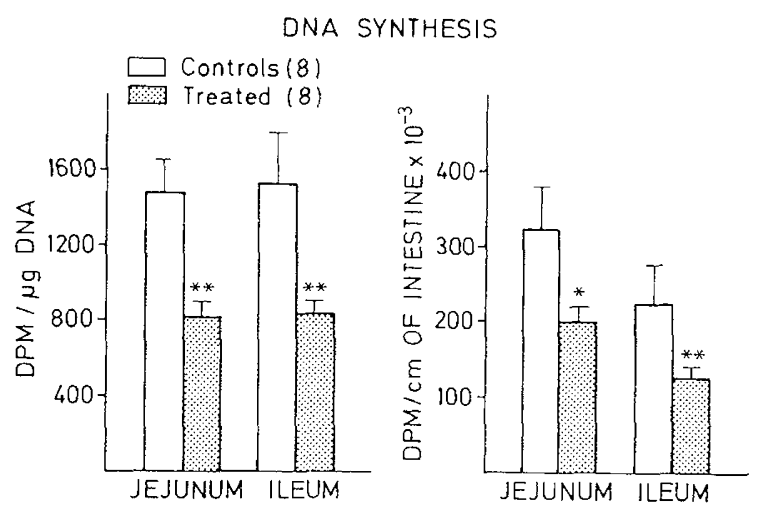

Fig. 6. Effects of pharmacologic doses of hydrocortisone $(2.0 \mathrm{mg} / 100$ $\mathrm{g}$ body wt) on DNA synthesis in the jejunum and ileum of sucklings. High doses of hydrocortisone produced a significant suppressive effect on $\left[{ }^{3} \mathrm{H}\right]$ thymidine incorporation in the jejunum $\left({ }^{* *} P<0.01, P 0.05\right)$ as well as in the ileum $\left({ }^{* *} P<0.01\right.$ vs controls).

of $\left[{ }^{3} \mathrm{H}\right]$ thymidine ((dis/min)/mg DNA or (dis/min)/cm of length) in the jejunum as well as in the ileum, to levels between $54-57 \%$ of the controls.

\section{DISCUSSION}

Our results confirm those reported by Herzfeld et al. (20) and show that between $\mathrm{d} 18$ and 22 the intestinal synthesis of thymidine kinase dramatically increases in weaning rats. The rise in thymidine kinase reaches a plateau at the fourth postnatal week and is concomitant with a 4-5-fold increase in crypt cell migration (16) and in intestinal DNA content. As shown in Figure 1. the weaning process has no effect by itself on the onset of enzymatic synthesis, which implies that the transition from rat milk to chow does not trigger the ontogenic changes observed; however, the activity plateau at the fourth postnatal week is reduced by two-thirds in non-weaned animals, suggesting that its level is dependent on diet. Very similar conclusions have emerged from studies on intestinal morphology $(26,27)$ and on enzymes of differentiated villous cells $(1,13,26)$. With regard to the nature of the dietary changes at weaning, we have examined whether the transition from a high fat-low carbohydrate diet (rat milk) to a high carbohydrate-low fat diet (chow) could be a determinant feature for the full expression of intestinal development. The amount of food consumed and protein intake were equivalent in the two litters of rats fed a mild-based diet either high in fat or high in carbohydrate (lactose). The results indicate that the proportion of carbohydrate relative to fat in the weaning diet is not critical for the developmental changes in DNA synthesis. Furthermore, by comparing the data in Figures 1 and 4, it can be seen that rats fed on mother's milk or a milk-based diet exhibited by d 22 lower kinase activities than did those normally weaned onto standard chow. There are essentially two differences between the chow pellets and the liquid diets that can account for this: 1) mixed carbohydrates (sucrose + lactose) in the chow diet versus lactose sole in the liquid diet, and 2) high versus low content in non-absorbable bulk. It is tempting to conclude that the last is the most important factor because non-absorbable bulk added to liquid elemental diets stimulates DNA synthesis in adult rat small intestine (8) and colon (36). Experiments to differentiate between the two are currently under progress. Also remaining to be established is whether the trophic effect of the adult diet on intestinal development represents a direct action of dietary components on the intestinal epithelium or is under hormonal mediation. Gastrin has been proposed as a good candidate for the role because pentagastrin treatment enhances intestinal development in non-weaned rats and antral gastrin concentrations are significantly lower in non-weaned than in weaned pups (27). Although this supports hormonal mediation, at present there is no confirming evidence. 
There is a large amount of evidence which indicates that glucocorticoids play a major role in intestinal development (14). A restricted period of maximal sensitivity of suckling rat intestine to precocious enzyme induction has been delineated by adrenalectomy and injection of low doses of cortisone $(13,17)$. These studies revealed a steady increase in responsiveness of sucrase induction during the suckling period, beginning on day 8 (17). During this period of high intestinal responsiveness to enzyme induction, we assessed the effects of low and high doses of hydrocortisone on parameters of intestinal DNA synthesis. Hydrocortisone was used because it is similar in activity to corticosterone, the natural steroid in the rat, but is longer acting. The dose of $0.5 \mathrm{mg} / 100 \mathrm{~g}$ body wt was assumed to be in the physiologic range because Loeb (29) has demonstrated that $0.3 \mathrm{mg} / 100$ $\mathrm{g}$ body wt per day was equivalent to almost twice the basal secretory rate of corticosterone. From our current results, it is clear that exogenous glucocorticoids, assessed under physiologic and pharmacologic conditions, are not trophic for the intestinal mass of the suckling rat and are not activators of DNA synthesis. Both low and high doses of the steroid were found to depress intestinal DNA content and DNA synthesis rates in the jejunum as well as in the ileum. Using low doses of hydrocortisone $(0.5$ $\mathrm{mg} / 100 \mathrm{~g}$ body wt) given for 4 consecutive $\mathrm{d}$ to 10 -d-old sucklings, we found a similar suppressive effect on DNA synthesis in the colon (4).

The effects of glucocorticoids on intestinal structure, cellular proliferation and DNA synthesis in growing rodents has been studied by several authors but has led to conflicting results. Our data are in agreement with Loeb's study (29) which reported that a single low dose of cortisone $(0.5 \mathrm{mg} / 60 \mathrm{~g}$ body wt) injected into weaning rats, caused a small and variable degree of suppression of DNA synthesis in the jejunum. At an earlier maturative stage, Tye and Burton (39) proved that the administrtion of dexamethasone to pregnant mice resulted in a $50 \%$ decrease of thymidine incorporation into the fetal gut. In the adult rat, the suppressive effect of glucocorticoids on intestinal DNA synthesis appears to be dose-time-related and long acting steroids are potent inhibitors of cryp cell mitosis $(25,37)$. Scott et al. (37) have very clearly demonstrated that prolonged treatment of adult rats with prednisone causes villous hypoplasia and marked depression of intestinal DNA, RNA, and protein content per unit length. Conversely, others have reported a maturative effect of glucocorticoids on mitotic index and crypt cell migration rate in suckling rat duodeno-jejunum but not in the ileum (16). This is not necessarily in contradiction because after cessation of large doses of steroids there is a rebound period of increased crypt cell division (38).

The assumption that glucocorticoids are not activators of DNA synthesis in suckling rat intestine is further supported by our data on the soluble fraction of thymidine kinase. Low doses of hydrocortisone failed to enhance the synthesis of the enzyme in sucklings and decreased the activity to a level $58 \%$ of the controls (not significant). Similarly, Herzfeld et al. (20) showed that the intestinal enzyme did not accumulate in neonates and sucklings after one dose of $2.5 \mathrm{mg} / 100 \mathrm{~g}$ body wt hydrocortisone but decreased in variable proportions (60-90\% of controls), depending on the age of the animals. The proportionality between thymidine kinase concentrations, DNA synthesis, and cell proliferation rates in normal intestinal development (18), regenerating liver (21), and rat tumors (33) is well documented. Multiple forms of thymidine kinase have been reported for rat tumors (33) and regenerating livers (32) but not for normal rat tissue $(12,19)$. The possibility that the non-response of thymidine kinase to hydrocortisone treatment could have been due to the rapid turnover of the enzyme in the small intestine (half-live less than $6 \mathrm{~h})(18)$ is unlikely because four injections of the steroid were made with last injection $2 \mathrm{~h}$ before sacrifice. Taken together, the present findings suggest that the dietary changes and the rise in glucocorticoid levels modulate the full expression of intestinal development in the suckling rat but do not initiate the ontogenic changes in DNA synthesis.
REFERENCES AND NOTES

1. Boyle, J. T. and Koldovsky, O.: Critical role of adrenal glands in precocious increase in jejunal sucrase activity following premature weaning in rats: negligible effect of food intake. J. Nutr.. /10:169 (1980).

2. Burton. K.: A study of the conditions and mechanism of the diphenylamine, reaction for the colorimetric estimation of deoxyribonucleic acid. Biochem. J., 62: 315 (1956).

3. Buts, J. P. and De Meyer, R.: Postnatal proximodistal development of the small bowel mucosal mass in growing rats. Biol. Neonate, 40:62 (1981).

4. Buts. J. P.. De Meyer, R., and Kolanowsky, J.: Ontogeny of cell proliferation and DNA synthesis in rat colon: role of glucocorticoids. Am. J. Physiol., 244: G469 (1983).

5. Doell, R. G. and Kretchmer, N.: Intestinal invertase: precocious development of activity after injection of hydrocortisone. Science. 143: 42 (1964).

6. Dohler. K. D., Gartner, K., Von Zur Muhlen. A., and Dohler, U.: Activation of anterior pituitary, thyroid, and adrenal gland in rats after disturbance stress. Acta Endocrinol.. 86: 489 (1977).

7. Dymsza, H. A., Czajka, D. M.. and Miller. S. A.: Influence of artificial diet on weight gain and body composition of the neonatal rat. J. Nutr.. 84: 100 (1964).

8. Ecknauer, R., Sircar, B.. and Johnson, L. R.: Effect of dietary bulk on small intestinal morphology and cell renewal in the rat. Gastroenterology, 81:781 (1981).

9. Galand, G. and Forstner, G. G.: Isolation of microvillus plasma membranes from suckling-rat-intestine. The influence of premature induction of digestive enzymes by injection of cortisol acetate. Biochem. J., /44: 293 (1974).

10. Giles, K. W. and Myers, M.: An improved diphenylamine method for the estimation of DNA. Nature. 206: 93 (1965).

11. Hageman. R. F., Sigdestad, C. P.. and Lesher, S.: A method for quantitation of proliferative intestinal mucosal cells on a weight basis: some values for $C$ 57 BL/6. Cell Tissue Kinet. 3: 21 (1970).

12. Hashimoto. T., Shiosaka. T.. Toide. H.. Okuda, H., and Fujii. S.: Thymidine kinase from normal and tumor tissues. Gann, 60:41 (1969).

13. Henning, S. J. and Sims, J. M.: Delineation of the glucocorticoid-sensitive period of intestinal devclopment in the rat. Endocrinology, 104: 1158 (1979).

14. Henning, S. J.: Postnatal development: coordination of feeding digestion and metabolism. Am. J. Physiol., 24l: G199 (1981).

15. Henning. S. J. and Guerin, D. M.: Role of diet in the determination of jejunal sucrase activity in the weanling rat. Pediatr. Res.. 15: 1068 (1981).

16. Herbst, J. J. and Sunshine, P.: Postnatal development of the small intestine of the rat. Pediatr. Res.. 3: 27 (1969).

17. Herbst. J. J. and Koldovsky, O.: Cell migration and cortisone induction of sucrase activity in jejunum and ileum. Biochem. J., 126:471 (1972).

18. Herbst, J. J.. Fortin-Magana, R.. and Sunshine, P.: Relationship of pyrimidine biosynthetic enzymes to cellular proliferation in rat intestine during development. Gastroenterology, 59: 240 (1970)

19. Herzfeld, A. and Raper. S. M.: The relative activities of thymidilate synthetase and thymidine kinase in rat tissues. Cancer Res. 40: 744 (1980).

20. Herzfeld. A. M. Raper. S. M.. and Gore. I.: The ontogeny of thymidine kinase in tissues of man and rat. Pediatr. Res., 14: 1304 (1980).

21. Hopkins, H. A.. Campbell. H. A.. Barbiroli, B., and Potter. V. R.: Thymidine kinase and deoxyribonucleic acid metabolism in growing and regenerating livers from rats on controlled feeding schedules. Biochem. J., 136: 955 (1973).

22. Johnson, L. R. and Guthrie, P. D.: Mucosal DNA synthesis: a short term index of the trophic action of gastrin. Gastroenterology, 67: 453 (1974).

23. Jones, R. E.: Intestinal absorption and gastro-intestinal digestion of protein in the young rat during the normal and cortisone-induced post-closure period. Biochem. Biophys. Acta, 274:412 (1972).

24. Koldovsky. O., Herbst. J. J., Burke. J., and Sunshine, P.: RNA and DNA in intestinal mucosa during development of normal and cortisone-treated rats. Growth, 34: 359 (1970).

25. Laguchev, S. S. and Avetisyan, A. A.: Effect of hydrocortisone on time parameters of the mitotic cycle of duodenal epithelial cells. Biull. Eksp. Biol. Med. 73: 86 (1972)

26. Lebenthal, E., Sunshine, P.. and Kretchmer, N.: Effect of prolonged nursing on the activity of intestinal lactase in rats. Gastroenterology, 62: 242 (1973).

27. Lichtenberger, L. and Johnson, L. R.: Gastrin in the ontogenic development of the small intestine. Am. J. Physiol.. 227: 390 (1974).

28. Little. J. M. and Lester. R.: Ontogenesis of intestinal bile salt absorption in the neonatal rat. Am. J. Physiol.. 239: G 319 (1980).

29. Loeb. J. N.: Corticosteroids and growth. N. Engl. J. Med.. 295: 547 (1976)

30. Lowry, O. H., Rosebrough, N. J.. Farr, A. L., and Randall, R. J. J.: Protein measurement with the folin reagent. Biol. Chem.. 193:265 (1951).

31. Machovich, R. and Greengard, O.: Thymidine kinase in rats tissues during growth and differentiation. Biochem. Biophys. Acta, 286: 375 (1972).

32. Nawata, H. and Kamiya, T.: Two molecular forms of thymidine kinase in the cytosol of regenerating rat liver. J. Biochem., 78: 1215 (1975).

33. Ohashi, M. and Taguchi, T.: Two forms of thymidine kinase in normal and tumor tissues of animals. Cancer Res., 36: 2.216 (1976).

34. Patt. J. A.: Factors affecting the duration of intestinal permeability to macromolecules in newborn animals. Biol. Rev., 52: 411 (1977).

35. Raul, F.. Simon, P. M., Kedinger, M.. Grenier, J. F., and Hafien, K.: Sucrase and lactase synthesis in suckling rat intestine in response to substrate administration. Biol. Neonate. 33: 100 (1978).

36. Ryan, G. P.. Dudrick, S. J.. Copeland. E. M., and Johnson, L. R.: Effects of various diets on colonic growth in rats. Gastroenterology, 77: 658 (1979).

37. Scott, J. Batt, R. M., Maddison, Y. E., and Peters. J.: Differential effect of 
glucocorticoids on structure and function of adult rat jejunum. Am. J. Phusiot. 241:G 306 (1981).

38. Tutton, P. J. M.: Proliferation of cpithelial cells in the jejunal crypts of adrenalectomized and adrenocortical hormone-treated rats Virchows $A$ rch. B. Cell. Pathol.. 13: 227 (1973).

39. Tye. L. M. and Burton. A. F.: Effects of dexamethasone on fetal mouse development. Biol. Neonatc. 38: 260 (1980).

40. The authors wish to thank Nadine De Keyzer and Monique Boelens for their expert technical assistance.
41. The authors are very grateful to Dr. Penelope Brock for her helpful comments on the manuscript.

42. Requests for reprint should be addressed to: Jean-Paul Buts. M. D.. Department of Pediatrics. University of Louvain. Clinique Saint-Luc, 10 avenue Hippocrate. B-1200 Brussels. Belgium.

43. This research was supported by grant no 3-4551/82 from the FRSM (Fonds de Recherche Scientifique Médicale) Belgium.

44. Received for publication September 24, 1982

45. Accepted for publication May 12, 1983.

0031-3998/84/1802-0150\$02.00/0

PEDIATRIC RESEARCH

Copyright (C) 1984 International Pediatric Research Foundation, Inc.

Vol. 18, No. 2, 1984

Printed in U.S.A.

\title{
Effect of External Inspiratory Loading on Ventilation of Premature Infants
}

\author{
SORAYA ABBASI, ${ }^{(30)}$ SHANAZ DUARA, THOMAS SHAFFER, AND WILLIAM W. FOX \\ Department of Pediatrics, Pennsylvania Hospital and the University of Pennsylania, School of Medicine, \\ Philadelphia, Pennsylvania [S.A.]; Department of Pediatrics, University of Maryland, Baltimore, Maryland \\ [S.D.]: Department of Physiology, Temple University School of Medicine, Philadelphia, Pennsylvania [T.S.]; and \\ Department of Pediatrics. The Children's Hospital of Philadelphia and the University of Pennsylvania School of \\ Medicine, Philadelphia, Pennsylvania, USA [W.W.F.]
}

\section{Summary}

The ventilatory response of 11 growing premature infants to external inspiratory resistive loads was evaluated. Air flow, tidal volume, minute ventilation, inspiratory duration and total breath duration were measured before and after application of a flow resistive load. A significant $(P<0.001)$ immediate decrease in minute ventilation and tidal volume was observed in all infants after load application. Minute ventilation and tidal volume remained decreased throughout the 10 -min study period. Minute ventilation and tidal volume for the group decreased to 48 and $\mathbf{5 0} \%$ of control mean value, respectively. In addition, there was a significant $(P<0.001)$ sustained increase in inspiratory time resulting in an increase in the ratio of inspiratory time/total respiratory time.

\section{Abbreviation}

$\mathrm{T}_{1} / \mathrm{T}_{\mathrm{T}}$, respiratory timing expressed as inspiratory time divided by total respiratory time

Recent monitoring techniques have demonstrated that airway obstruction occurs frequently in premature neonates recovering from respiratory disease $(1,28)$. Upper airway obstruction has been shown to produce significant ventilatory deficiency particularly in preterm infants $(4,14)$ and has been suggested as one of the etiologies of apnea $(14,24)$. Several investigators have shown that upper airway obstruction can result from passive or active neck flexion, occlusion of the oropharynx by the tongue due to sleep-induced relaxation of genioglossus muscle, or edema of the upper airway in infants with nasopharyngitis $(20,25,27)$.

Although airway obstruction can occur frequently in premature infants, there is little information on the physiologic response to either partial or complete obstruction. The ventilatory response of premature infants to a flow resistive load to simulate partial airway obstruction was studied (6); however, these infants were only exposed to this load for the duration of one breath. In order to understand the role of different types of flow resistive loads in infants, it may be necessary to evaluate inspiratory and expiratory loads separately.

The purpose of this study is to evaluate the immediate and sequential effects of an external inspiratory flow resistance on the ventilatory response of growing premature infants. These data should be useful in understanding compensatory mechanisms involved in partial airway obstruction.

\section{MATERIALS AND METHODS}

Eleven infants were studied after recovery from respiratory disease. They did not have cardiorespiratory diseases at the time of the study or any evidence of intracranial hemorrhage during the course of hospitalization. The infants had estimated gestational ages ranging from 28-36 wk, a mean birth weight of 1.50 $\pm 0.13 \mathrm{~kg}$, and mean study age of $4.15 \pm 1.10$ postnatal wk. They were studied in sleep approximately $30 \mathrm{~min}$ after a feeding.

Ventilatory response was evaluated with the infant in the supine position breathing room air, through a soft rubber face mask (Ohio Products), which tightly covered the infant's mouth and nose. A heated pneumotachygraph (Hewlett-Packard 21069) was used to measure air flow. The pneumotachygraph was attached to the face mask and a one-way nonrebreathing $\mathrm{T}$-valve. Flow signals were integrated to produce tidal volume by a Hewlett-Packard flow-integrator (NO. 8802A). The end tidal $\mathrm{CO}_{2}$ was measured by a Cavitron Anard Gas Analyzer at a pump flow rate of $100 \mathrm{ml} / \mathrm{min}$ through continuous sampling from the mask air. A Litton Oxymonitor (Model No. 23604803) was used for transcutaneous oxygen tension monitoring.

A standard length endotracheal tube, $2.5 \mathrm{~mm}$ in diameter, was used for the inspiratory flow resistive load. The endotracheal tube was narrowed by a central adjustable screw clamp, $3 \mathrm{~mm}$ wide, to produce different resistances (18). For the study, each infant was evaluated with two different resistances. These resistances $\left(\mathrm{R}_{1}=100 \mathrm{~cm} \mathrm{H} \mathrm{H}_{2} \mathrm{O} \cdot \mathrm{L}^{-1} \cdot \mathrm{s}^{-1}\right.$ and $\mathrm{R}_{2}=150 \mathrm{~cm} \mathrm{H} \mathrm{H}_{2} \mathrm{O} \cdot \mathrm{L}^{-1}$. $\mathrm{s}^{-1}$ at $1 \mathrm{~L} / \mathrm{min}$ flow rate) were selected as a mid and mid-high resistive loads by a preliminary testing of 10 different resistances 